国際教育協力の現状と課題

\title{
東南アジア地域における国際教育協力の 現状と課題——自立発展的」な教育改革支援へ向けて一
}

廣里 恭史

(名古屋大学)

\section{はじめに}

概ね持続的な成長軌道にあった東南アジア地域は、1997年に端を発するアジア 危機によって広範で深刻な影響を受けた。しかし、以降の回復は目覚しく、むし ろこの危機からの克服を契機として、教育を含む様々な分野において構造変化を 伴う改革が進行中である。本稿の目的は、変動期にある東南アジア地域における 国際教育協力の現状と課題を論じることである ${ }^{(1)}$ 。まず、この地域における近年 の教育状況と国際機関 (主に世界銀行・アジア開発銀行)の取り組みを手掛かりに 国際教育協力が直面する課題を検討する。次にこれら課題に対処するための新た な協力アプローチの特徵に言及し、国際教育協力における能力開発の重要性と日 本の役割を論じる。最後に、この地域に抢ける国際教育協力のあり方を「自立発 展的」な教育改革支援として主題化し、将来展望を試みる。

\section{1. 国際教育協力の現状と課題}

国際教育協力が本格的に始まったのは1960年代初頭のことであり、すでに40年 以上が経過している ${ }^{(2)}$ 。その間、先のアジア危機の影響を受けつつも、東南アジ ア各国の教育状況は着実に進展している。しかし、残された問題も多く、同地域 においてもテロ・紛争や自然災害からの復興・開発といった新たな課題も浮上し ている。そうした状況で、同地域に共通する国際教育協力の主な課題は、(1)「万 人のための教育 (Education for All: EFA)」目標の達成、(2)地方分権化の促進、(3)高 等教育と職業技術教育・訓練への関心、といった 3 分野に集約されよう ${ }^{(3)}$ 。 


\section{（1）EFA 目標の達成}

1996年に、OECD (経済協力開発機構)のDAC (開発援助委員会) は「新開発戦略」 を打ち出し、最も重要な原則として、開発の主体を途上国とするオーナーシップ の確立、及び途上国と援助機関（NGO を含む）並びに援助機関の間でのパート ナーシップの構築を強調した。教育分野では、初等教育の完全普及と初中等教育 での男女格差の解消が目標とされた (4)。この流れは、2000年 4 月の「世界教育 フォーラム」での「ダカール行動枠組み」採択へ引き継がれ、具体的には 6 項目の EFA 目標が掲げられた(5)。さらに、同年 9 月の国連総会において EFA 目標を含む 「ミレニアム開発目標（Millennium Development Goals: MDGs）」が採択され、基礎 教育重視の国際思潮として定着した ${ }^{(6)}$ 。しかし、EFA 目標自体は未達であり、東 南アジア地域でも基礎教育に多くの課題を残している国々がある(7)。以下では、 MDGs と合致する二つの EFA 目標、すなわち2015年までの「初等教育の完全普及 (MDG2)」と「教育における男女格差の解消（MDG3）」に焦点を合わせ、モニタリ ング指標（初中等教育の純就学率、5 年次残存率、男女格差、若年層識字率）に よって、同地域の教育状況を照射しながら国際教育協力の課題を検討する。

表 1 は東南アジア地域における1998年と2001年の初中等教育の就学状況と若年

表 1 東南アジア地域における初中等教育と識字の現状

\begin{tabular}{|c|c|c|c|c|c|c|c|c|c|c|c|}
\hline & \multicolumn{4}{|c|}{ 初等教育純就学率 (\%) } & \multirow{3}{*}{$\begin{array}{c}5 \text { 年次残 } \\
\text { 存率 }(\%) \\
2000 \text { 年 }\end{array}$} & \multicolumn{4}{|c|}{ 中等教育純就学率(\%) } & \multirow{2}{*}{\multicolumn{2}{|c|}{$\begin{array}{c}\text { 若年層 } \\
\text { 識字率(\%) } \\
\text { 2002年 }\end{array}$}} \\
\hline & \multicolumn{2}{|c|}{ 1998年 } & \multicolumn{2}{|c|}{ 2001年 } & & \multicolumn{2}{|c|}{ 1998年 } & \multicolumn{2}{|c|}{ 2001年 } & & \\
\hline & 平均 & GPI ${ }^{1)}$ & 平均 & GPI & & 平均 & GPI & 平均 & GPI & 女性 & GPI $^{3)}$ \\
\hline インドネシア & - & - & 92.1 & 0.99 & 89.2 & - & - & 47. $4^{4)}$ & $0.95^{4)}$ & 97.6 & 0.99 \\
\hline フィリピン & - & - & 93.0 & 1.02 & 79.3 & 50.8 & 1.09 & 56.5 & 1.20 & 95.7 & 1.01 \\
\hline ベトナム & 96.7 & - & 94.0 & $0.94^{5)}$ & 89.0 & 49. 4 & - & 63.5 & - & - & - \\
\hline カンボジア & 82.5 & 0.91 & 86.2 & 0.93 & 70.4 & 14.3 & 0.54 & 20.8 & 0.60 & 75.9 & 0.90 \\
\hline ラオス & 80.2 & 0.92 & 82.8 & 0.92 & 79.3 & 26.7 & 0.79 & 31.4 & 0.81 & 72.7 & 0.85 \\
\hline ミャンマー & 82.5 & 0.99 & 81.9 & 1.00 & 59.9 & 31.2 & 0.99 & 35.3 & 0.94 & 91.1 & 1.00 \\
\hline
\end{tabular}

注 1) GPI は、ジェンダー・パリティ指数であり、男子純就学率に対する女子純就学率の割合として計算され ている。

2) 15 歳から24歳まで。

3) 男性識字率に対する女性識字率の割合。

4) 1999年のデータ。

5 ） 2000年のデー夕。

出所) UNESCO, EFA Global Monitoring Report 2005: The Quality Imperative, Paris: UNESCO Publishing, 2004 ; 及 び国連開発計画队間開発報告書2004』国際協力出版会、2004年、より筆者作成。 
層識字率を示している ${ }^{(8)}$ 。初等教育ではインドネシア、フィリピン、ベトナムの 純就学率が90\%を超えている。カンボジアとラオスでは、純就学率が向上してい るものの2001年では未だに $80 \%$ 台前半であり男女格差も顕著である。ミャンマー は、純就学率に若干の後退傾向が見られるが、男女格差は是正されている。また、 5 年次残存率は、インドネシアとベトナムを除いて $80 \%$ 以下で、2 割以上の児童 が中途退学している。中でもミャンマーのそれは $60 \%$ に満たない。初等教育状況 は若年層識字率とも密接に関係しているが、ラオスとカンボジアは70\%台と低く、 男女格差も大きい。さらに、中等教育状況を1998年と2001年で比較すると、純就 学率が着実に向上しているものの、50\%以上はフィリピンとべトナムのみである。 特に、カンボジアは約 $20 \%$ 、ラオスは約 $30 \%$ と低水準に留まっており、両国では、 2001 年の男女就学格差を示す「ジェンダー・パリティー指標 (GPI)」がそれぞれ

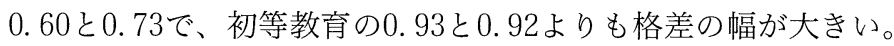

なお、表 1 からは直接論じられないが、就学格差には性差の他に地域や所得に よる格差も深刻で、貧困層、少数民族、障害者等の社会的弱者層が初中等教育機 会からとり残されている。初等教育の純就学率が全国平均で一定水準を超えても、 それ以上の改善は残された地域や集団における初等教育の完全普及と格差是正が 必要となる。一方で、初等教育の純就学率が90\%を超えているインドネシア、 フィリピン、ベトナムでは中等教育の普及と初中等教育の質向上が優先的課題で あり、その他の国々でも、教育の質低下を招くような教育機会の拡大政策を続け るべきではない。要約するならば、初中等教育普及が遅れている残された地域や 集団における格差の是正を図りつつ、質の高いEFA（Quality Education for All)の 達成が東南アジア地域における国際教育協力の最大の課題といえるであろう ${ }^{(9)}$ 。

\section{（2）地方分権化の促進}

一般に、質の高い基礎教育の普及は、途上国政府が担うべき公共政策として位 置づけられてきた。しかし、今日の途上国は、新自由主義的な思潮に影響を受け た教育行財政の地方分権化の推進と、市場原理に基づく規制緩和や民営化を通じ た教育改革を志向している。従って、質の高い基礎教育普及の方策としては、政 府の役割を重視しつつも、中央と地方の役割分担の見直しや市場・競争原理の導 入によって、基礎教育普及プロセスにおける効率性が追求されている。とりわけ 
教育部門運営に関しても権限・財源を地方へ移譲し、意思決定過程に地方政府や 地域社会が積極的に関与し、これら主体の実施責任能力が高まれば、費用対効果 の高い運営が可能とされている ${ }^{(10)}$ 。加えて、東南アジアの国々は多文化・多民 族・多言語の地域社会を抱えて打り、地域や民族によって教育の捉え方が異なっ ている。そこに画一的な基礎教育普及政策を実施しても現地ニーズに合致せず、 かえって教育部門運営の非効率性を促進しかねない。従って、EFA 目標の達成に 関わる基礎教育支援の大半は、地方分権化の文脈で実施されている。例えば、世 界銀行によるべトナムの「不利な児童たちへの初等教育プロジェクト」とラオスの 「第二次教育開発プロジェクト」、アジア開発銀行によるインドネシアの「地方分 権的な基礎教育プロジェクト」は、就学水準の低い貧困地域や少数民族地域を対 象とし、プロジェクトの実施責任を概ね地方政府や地域社会に委ねている ${ }^{(11)}$ 。

中央と地方の役割分担の規定や学校の効率的な運営は、先進国に抒いても教育 改革の争点でもあるが、同時代の途上国教育改革の背後にある、効率性を重視し た新自由主義の影響についての考察が十分になされているとはいい難い。途上国 にはこのような考方方が根付く制度的諸条件が整っておらず、むしろ排他的な競 争や選別が激化し、しばしば弱者(最貧国や途上国の貧困層)が切り捨てられ、国 家間や地域間の格差が増大するという見方もある ${ }^{(12)}$ 。グローバリゼーションの 深化が避けられない状況にあって、そのマイナス面あるいは「影」の部分を見極め ることは不可欠である。中央と地方の役割分担の議論が一層複雑になるもう一つ の要因は、教育行財政の中央レベルからの権限・財源移譲を巡り地方政府と教育 関連省庁の各級機関との関係が曖昧に規定され、地方レベルや学校現場で混乱が 生じるか、あるいは法令で規定されていても実効が伴わない場合が多いことであ る。インドネシアやフィリピンでは、急激な地方分権化によって、実施上の混乱 が生じたし、ベトナムのように、初等教育行政に関わる各級機関がいわゆる「二 重の従属」関係にある場合が指摘されている(13)。

\section{（3） 高等教育と職業技術教育·訓練への関心}

1990年代以降の基礎教育重視という国際思潮は、高等教育や職業技術教育・訓 練への批判とそれらへの政府支出の削減を伴った。しかし、近年のグローバリ ゼーションの深化と国際競争の激化、情報通信技術の進歩等が推進する知識社会 
化によって教育分野における高等教育と職業技術教育・訓練の役割が見直されて いる ${ }^{(14)}$ 。1998年にユネスコが主催した「高等教育世界会議」や2000年の世界銀行 とユネスコとの共同報告書の刊行によって ${ }^{(15)}$ 、途上国の発展段階に応じた高等 教育支援へ向けた指針が打ち出された。その際の重要な政策課題は、いかに高等 教育機関の法人化や民営化を進めるべきかであり ${ }^{(16)}$ 、具体的な協力領域は、戦 略的計画への支援、大学への競合的予算配分方式の導入、評価・認定制度の強化 に至るまで多岐にわたっている。例えば、世界銀行は、カンボジアにおいて高等 教育機関の評価・認定制度創設を支援し、アジア開発銀行は、ラオスにおいて 「中等教育後の合理化プロジェクト」を実施した ${ }^{(17)}$ 。後者はラオス国立大学の統 合化と自治化支援を含む戦略性の高いもので、高等教育行財政の基盤整備に貢献 しょうとした。職業技術教育・訓練分野では、市場・競争原理の導入によって労 働市場の需要サイドに近い民間機関主導の実施形態が奨励されている。フィリピ ンでは、アジア開発銀行による「技術教育・技能開発プロジェクト」に扔いて技能 開発基金が創設され、民間訓練機関の質改善と公的機関による民間部門との連携 が強化されつつある(18)。

\section{2. 国際教育協力の新たなアプローチ}

このような諸課題に対処する新たな国際教育協力のアプローチとして二つの方 向性が台頭している。一つは、セクター・ワイド・アプローチ（Sector-Wide Approach: SWAp) によるセクター・プログラム支援であり、もう一つは、準地域 的な教育協力を含む「大メコン川流域圈 (Greater Mekong Subregion: GMS) プログ ラム」である。

\section{（1）SWAp によるセクター・プログラム支援}

EFA 目標達成を視野に入れつつ、教育部門のサブセクター間のバランスを図 り、途上国の教育改革プロセス自体を支援しょうとするのが SWAp によるセク ター・プログラム支援である ${ }^{(19)}$ 。国際協力全般のあり方として、整合性を欠い たプロジェクト型の協力形態への反省に基づき、1990年代から効率的な援助調 整・協調を通したセクター・プログラム支援が目指されてきた ${ }^{(20)}$ 。より直接的 には、国際通貨基金・世界銀行が主導する貧困削減戦略文書（Poverty Reduction 
Strategy Paper: PRSP) において教育部門が貧困削減に重要な役割を担っているこ $と^{(21)}$ 、イギリス、スウェーデン、欧州連合等が貧困削減のための効率的な援助 協調体制を構築する立場を鮮明にしたことが背景にある(22)。さらに、SWApによ るセクター・プログラム支援が進化した協力形態に「一般財政支援」方式がある。 地方分権化の流れが定着することによって、援助資金を受け入れる途上国財政が 各部門の省庁所管より財務を司る中央政府(財務省)によって所管され、そこから 地方政府へと移譲されつつある。途上国政府の説明責任能力や援助資金フローの 透明性が確保されることが前提であるが、援助資金を財政の一部として過渡的に 受け入れることで、究極には、途上国自身が財政的に自立可能となることを目指 す協力形態とされている。

SWAp は、すでに複数のサハラ以南のアフリカ諸国で導入されているが、東南 アジア地域でも、先駆的な例として、カンボジアがあり、SWAp 導入の準備を具 体的に進めている国として、ベトナムとラオスがある ${ }^{(23)}$ 。カンボジアでは、2001年 にアジア開発銀行によって承認された「教育セクター開発プログラム」において、 政府が「優先的行動プログラム (Priority Action Program: PAP)」と呼ばれる経常予 算を支援する「一般財政支援」のための特別スキームを創設し、PAPへの資金援助 を通して教育部門全体の均衡がとれた発展を目指す政策・財政支援が行われた (24)。さらに、2004年に同じくアジア開発銀行によって承認された「第二次教育セ クター開発プログラム」では、中等教育機会の拡大と基礎的な技能訓練に対する 支援が盛り込まれている。このように、カンボジアでは、支援対象・範囲が初等 教育から中等教育と技能訓練へと拡大され、よりバランスのとれた包括的な教育 改革支援が目指されている(25)。

次に、質の高いEFA 実現を担保する方策として、ベトナムで導入されている 「基礎的な学校の質水準 (Fundamental School Quality Level: FSQL)」といった概念が ある。これは、途上国政府と援助機関が全国的に均一に保障されるべき最低限の 教育の質に関して同意した上で、「一般財政支援」を含む融資を実施するものであ る。初等教育の FSQL に関しては、世界銀行による「不利な児童たちへの初等教 育プロジェクト」において教育訓練省が保証すべき教育の質として規定され、前期 中等教育に関しては、アジア開発銀行による「第二次前期中等教育プロジェクト」 において教育訓練省が同様の FSQL を開発することが融資条件とされている ${ }^{(26)}$ 。 
しかし、実際には、SWApによるセクター・プログラム支援や「一般財政支援」 が成り立つ前提条件としてのオーナーシップやパートナーシップに対する懸念が ある ${ }^{(27)}$ 。これらは、前述のように DAC 「新開発戦略」の根幹を成しているが、セ クター・プログラム策定過程そのものに援助機関の雇用する外国人コンサルタン トへの依存傾向が散見される ${ }^{(28)}$ 、また、途上国政府と援助機関あるいは援助機 関同士でパートナーシップが構築され得るのかという問題があり ${ }^{(29)}$ 、お互いの 利害調整に予見されていた以上の労力と時間が費やされ、SWAp が意図する援助 調整コストの軽減には至っていない場合が多い。仮に、SWAp が成功し「一般財 政支援」に踏み切ったとしても、時間的なフレームを念頭に置いた出口政策を明 確に織り込むことができず、かえって途上国の援助機関や外国人コンサルタント への依存体質だけが強化されることにもなりかねない。さらに、セクター・プロ グラム支援の実施上の問題も枚挙に㗇がなく、援助手続きの共有化や簡略化を目 指してたはずが、かえって煩雑になる場合もあるし、後述するような途上国にお ける制度や実施能力の欠如、援助機関側の能力や経験不足の問題も指摘される。 このような問題を孕みつつも、SWAp によるセクター・プログラム支援や「一般財 政支援」への方向性は不可逆的であり、実施上の経験を重ねることによって国際 教育協力の新たなアプローチとして今後も進化を遂げていくことと思われる。

\section{（2）地域的教育協力の可能性:GMS プログラムを中心に}

東南アジア地域に抢けるもう一つの新たな協力アプローチは、より大きな市場、 規模の経済、効果的な分業をもたらすとされる準地域協力である。その代表例が アジア開発銀行を調整・推進機関として1992年に発足した GMS プログラムであ る。GMS は、カンボジア、ラオス、ミャンマー、タイ、ベトナム、そして中国 (雲南省のみ)にまたがり、約 2 億 5 千万人を擁する潜在的成長力の高い経済圈で ある。GMS プログラムは、東南アジア地域においてもユニークな存在であり、 他の準地域協力のモデル・ケースとなっている ${ }^{(30)}$ 。GMS プログラムは、2001年 以降、フェーズ 2 にり、運輸、通信、環境・自然資源管理、観光振興、人的資 源開発などに関わる10の基幹プロジェクトで構成されている(31)。教育部門は人 的資源開発の下部部門(他に保健と労働)の一つとして位置づけられ、フェーズ 2 では教育部門における取り組みが最優先されている。 
GMS 人口の半数強が潜在的労働力とみなされているが、その労働力はかなり の部分が遊休化しており、成長の規模とスピードに対応できる人材が各分野で不 足している。また、若年層識字率の低さや初中等教育の未整備、健康状態の悪さ などによって労㗢生産性も高いとはいえない。インドシナ諸国やミャンマーは未 だ初等教育の完全普及を達成しておらず低雇用の一因となっているが、実際の雇 用に結びつくには、より高度な技術教育や職業訓練が必要であり、GMS 内にお ける技能の標準化、技能検査や評価システムの整備、労働市場情報サービスの充 実、等が急務となっている。また、初中等教育の整備は、基本的に GMS 各国内 の課題であるが、地方分権化政策の運営や教育の質改善が共通の政策課題である ことから、これらが今後の優先プロジェクトになっている ${ }^{(32)}$ 。

\section{（3）能力開発の重要性}

国際教育協力の諸課題を解決できるかどうかは、途上国政府そして援助機関の 双方が課題解決に必要な能力を持つことができるか、すなわち、適切な能力開発 (Capacity Development) が伴うことにかかっている。とりわけ、地方分権化にお けるEFA目標の達成には、SWApによるセクター・プログラム支援や「一般財政支 援」といった新しい協力アプローチが導入されつつあり、地方政府や学校レベル における能力開発の重要性が増している。このような試みの成否は、真のオー ナーシップやパートナーシップの構築という基本原則を念頭に置きつつも、途上 国側の制度未整備、実施能力の欠如、援助機関側の能力と経験不足というょうに、 双方における実施上の問題を克服する必要がある ${ }^{(33)}$ 。本来ならば教育部門運営 を効率化するはずのセクター・プログラム支援が、途上国政府や援助機関の実施 能力を凌ぐものとなってしまえば本末転倒である。それでも、能力開発の重要性 が認識され、国レベルの個別案件としては様々に取り組まれてる。しかし、地方 分権化によって能力開発の対象があまりにも拡散され、また重複する場合もある。 能力開発の担い手も、援助機関が雇う外国人コンサルタントであることが多く、 その方法論は大方整合性を欠き、体系的に整理されていない。各国の文脈に沿っ た能力開発ニーズを満たす必要がある一方で、東南アジア地域に共通する能力開 発の方法論や制度・仕組みを見出すことが重要である。

その意味で、GMS プログラムにおける能力開発への取り組みは注目に值する。 
開発運営の「プノンペン・プラン」を発足させ、域内の主な教育研修機関と協力し、 行政官の研修を実施している ${ }^{(34)}$ 。準地域的な協力を促進するために、多部門・ 多分野のマルチセクター・アプローチを重視し、例えば、HIV/AIDS との関連で、 教育と保健にまたがる就学前教育、学校保健、麻薬撲滅のための教育、などの研 修が行われている。しかし、教育は「プノンペン・プラン」における限られた一分 野であり、この枠組みにおいては能力開発の中心にはなり得ないといった限界も ある。今後はこの「プノンペン・プラン」と連携を図りつつも、教育部門に特化す る能力開発の方法論の確立や制度・仕組みの構築が望まれる所以でもある。

\section{3. 国際教育協力における日本の役割}

翻って、日本は様々な次元において東南アジア地域との関わりを深めてきた。 この地域における日本の ODA は紆余曲折を経つつも重要な役割を果たしてきた し、教育協力もその一翼を担ってきた。その中で、2002年の G8 カナナキス・サ ミットにて日本主導によって採択された「成長のための基礎教育イニシアティブ (Basic Education for Growth Initiative: BEGIN)」や2003年に改訂された新「ODA 大 綱」において MGDs 重視とEFA 目標の達成が一層明確に打ち出されている。特に、 BEGINにおいて注目すべきは、基本理念としての自助努力支援と重点分野とし て教育マネジメント能力改善への支援を含んでいることである。このような基本 理念と重点分野は、前述した新しいアプローチにおける能力開発の重要性を補完 するものであるし、ベトナムの「初等教育セクタープログラム開発調査」やインド

ネシアの「地域教育開発支援」等の先駆的な試みもある ${ }^{(35)}$ 。

同時に、この地域においては、留学生借款や留学生支援無償が供与されている し、従来からの理数科教育と教員教育支援がある。さらに「アセアン工学系高等 教育開発ネットワーク(通称：SEED-Net)」が形成されているように、まさに教育 部門のサブセクター間のバランスが考慮されねばならない。加えて、タイやマ レーシアのような中所得国の存在によって、被援助国から相互利益と合意形成に 基づく新しい協力関係の確立が模索されている ${ }^{(36)}$ 。今後の日本の国際教育協力 は、二国間協力(特にインドシナ諸国)においてセクター・プログラム支援の経験 を積みつつ自らの能力開発を強化すること、タイ等との二国間の連携によってこ の地域の第三国の課題に取り組むこと、また、GMS プログラムのような地域 
ネットワークを活用し、地域的な課題に取り組むこと、が優先されてよいであろ う。

\section{おわりに：自立発展的な教育改革支援へ向けて}

21世紀の東南アジア地域における国際教育協力のビジョンは、MDGs や EFA 目 標を達成するために、自らの教育改革を「自立発展的」に推進する途上国固有の能 力を構築することではあるまいか。東南アジア地域は、グローバリゼーションの 深化により、一層の地方分権化や民営化などの新たな挑戦を受けているが、教育 部門のガバナンス能力は依然として十分ではなく、地方教育行政や学校の計画・ 運営能力は非常に脆弱で、必要な教育改革の推進力となっていない。現状では、 途上国自らが教育の課題を発見・分析し、自国の教育計画や戦略・政策を立案し、 SWAp などの援助調整・協調メカニズムを通したセクター・プログラム支援によ る教育改革を担う自国の専門家集団は育ち難い。

近年、日本においても比較教育学や比較教育研究者による国際教育協力への関 わりが様々な形で提起されている ${ }^{(37)}$ 。セクター・プログラム支援の基盤となる、 途上国のダイナミックな教育改革プロセスの解明は比較教育研究者の責務そのも のであろうし、中・長期的には提起されたような「自立発展的」な教育改革能力開 発のために果たすべき役割があると考える ${ }^{(38)}$ 。東南アジア地域に共通する能力 開発の方法論の確立や制度・仕組みの構築は一つの試金石となるであろう。

\section{(注)}

（1）「国際教育協力」とは国境を越えて教育分野で他国 (他者)を支援することであり、支 援の担い手と受け手との互恵的な関係を意味する。従って、支援の担い手から受け手 への一方的な関係を示唆する「教育援助」とは区別されることが多い。内海成治『国際教 育協力論』世界思想社、2001年 ; 千葉晃弘・永田佳之「国際教育協力の歴史」千葉晃弘監 修『国際教育協力を志す人のために』学文社、2004年、3-23頁 ; 及び澤村信英「教育開発」 内海成治編『国際協力論を学ぶ人のために』世界思想社、2005年、207-222頁。

(2) 東南アジア地域を含む国際教育協力の歴史的経緯と変遷は、千葉・永田、同上論 文 ; 江原裕美「開発と教育の歴史と課題」江原裕美編『開発と教育一国際協力とこどもた ちの未来』新評論、2001年、35-100頁 ; 及び黑田一雄・横関裕見子「序章：国際教育協力 の潮流」黒田一雄・横関裕見子編『国際教育開発論一理論と実践』有斐閣、2005年、1-13 頁、を参照。 
（3）アジア地域全体の教育開発・協力の現状と展望は、Hirosato, Yasushi, "New Challenges for Educational Development and Cooperation in Asia in the $21^{\text {st }}$ Century: Building Indigenous Capacity for Education Reforms," Journal of International Cooperation in Education, Vol.4, No.2, 2001, pp.1-24 ; 及び Asian Development Bank (ADB), Education and National Development in Asia: Trends, Issues, Policies, and Strategies, Manila: ADB, 2001, 等を参照。

(4) OECD, Shaping the 21st Century: The Contribution of Development Co-operation, Paris: OECD, 1996.

(5)これらは、(1)就学前保育・教育の拡大と改善、(2)2015年までに良質の初等義務教育 を無償で保障、(3)青年・成人の学習ニーズの充足、(4) 2015 年までに成人識字率を $50 \%$ 改善、(5)2005年までに初等・中等教育における男女格差の解消、6)読み書き、計算及 び基本的な生活技能取得のための教育の質改善、である。UNESCO, The Dakar Framework for Action-Education for All: Meeting Our Collective Commitments, Paris: UNESCO Publishing, 2000.

（6）北村友人「国際教育をめぐる公共性と政治性一グローバル・ガバナンスのメカニズム に関する考察」『インターカルチュラル：日本国際文化学会年報』第 3 号、2005年、58-79 賁; 及び千葉・永田、前揭論文。世界銀行は、比較的成果を上げやすいと見込まれる 国々の初等教育分野へ集中的な援助を実施する「ファスト・トラック・イニシアティブ (Fast Track Initiative: FTI)」を2003年より導入している。東南アジア地域ではべトナムが FTI 対象国であり、カンボジアもFTIへの参加を模索している。北村友人「基礎教育へ の国際的な資金援助の試み一 EFA ファスト・トラック・イニシアティブ導入の背景と 課題」『国際協力研究』第20巻、第 1 号、2004年、53-63頁。一方、ユネスコは、EFA 目標 の達成を世界規模でモニタリングする仕組みを創設している。UNESCO, EFA Global Monitoring Report 2005: The Quality Imperative, Paris: UNECO Publishing, 2004.

(7) 初等教育の完全普及という目標は、1960年に採択された「カラチ・プラン」に遡る。 また、1990年の「万人のための教育世界会議」においては、2000年までに全ての人に初等 教育機会を保障することが宣言された。EFA 目標が形を変えて再三に繰り返されてい ることは、その達成の困難を示しているが、その困難さは、就学人口の増加や資金不 足のみに限らない。日本の教育経験に基づくならば、初等教育発展段階によって取る べき政策が異なっており、途上国においても EFA 目標を達成するための政策をほぼ一 律に適用することは妥当ではないとの指摘がある。金子元久「初等教育の発展課題一日 本の経験と発展途上国への視点」米村明夫編『世界の教育開発一教育発展の社会科学的 研究』明石書店、2003年、27-41頁。

(8) シンガポール、ブルネイ、タイとマレーシアを除く。タイとマレーシアもすでに被 援助国の立場を脱却する強い政治的意思を表明している。ただし、ミャンマーは、教 育協力の潜在的な対象国であるが、目下の政治状況によって、援助機関との教育協力 
の範囲は限定的である。

(9) World Bank, Education Sector Strategy, Washington, D.C.: The World Bank, 1999 ( 黒田一 雄・秋庭裕子訳『世界銀行の教育開発戦略』CICE 丵書 1 、広島大学教育開発国際協力七 ンター、2001年 ) ; 及び Nielsen, H. Dean, and Cummings, William K., eds., Quality Education for All: Community-Oriented Approaches, New York: Garland Publishing, 1997.

(10) McGinn, Noel F., and Welsh, T., Decentralization of Education: Why, When, What and How? Paris: IIEP, UNESCO, Fundamentals of Educational Planning 64, 1999.

(11) World Bank, Project Appraisal Document (PAD), Viet Nam, Primary Education for Disadvantaged Children, Washington, D.C., 2002; World Bank, PAD, Lao People's Democratic Republic (PDR), Second Education Development Project, Washington, D.C., 2004 ; 及び ADB, Report and Recommendation of the President (RRP), Indonesia, Decentralized Basic Education Project, Manila, 2001.

(12) 吉良直「世界銀行の教育地方分権化政策のジレンマ」江原編、前掲書、271-286頁。

(13) すなわち、省教育訓練局は、省級人民委員会の指導・管理に服する一方、中央の教 育訓練省の指導・検査に服する。県教育訓練課は、県級人民委員会の指導・管理に服 する一方、省教育訓練省の指導・検査に服することになる。石塚二葉「ベトナムに拀け る各級行政機関間の関係一初等教育行政を事例として」石田暁恵・五島文雄編『国際経 済参入期のベトナム』アジア経済研究所、2004年、387-417頁。

(14) D. チャプマンと A. オースティンは、基礎教育普及による一定の成果によって、中等 以降の学校段階への就学圧力が高まってきていること、ある国ではむしろ基礎教育「偏 重」のために労働力の技能に限界が生じていることを指摘している。Chapman, David W., and Austin, Ann E., eds., Higher Education in the Developing World: Changing Contexts and Institutional Reponses, Westport, Connecticut: Greenwood Press, 2002.

(15) World Bank, Higher Education in Developing Countries: Peril and Promise, Washington, D.C.: The World Bank, 2000.

(16) 日本比較教育学会編「特集 高等教育改革の比較研究一法人化・民営化を中心として」 『比較教育学研究30』2004年、3-88頁。

(17) ADB, RRP, Lao PDR, Postsecondary Education Rationalization Project, Manila, 1995.

(18) ADB, RRP, Philippines, Technical Education and Skills Development (TESD) Project and Fund for TESD, Manila, 2000.

(19) King, Kenneth, and Buchert, Lene, eds., Changing International Aid to Education: Global Patterns and National Contexts, Paris: UNESCO Publishing, 1999 ; 横関祐見子「援助強調へ の対応」内海編、前揭書、299-314頁; 及び拙稿「アジア地域への教育協力一アジア開発 銀行と教育開発・改革をめぐる政治経済学の構想」江原編、前掲書、181-208頁。

(20) セクター・プログラムを最初に定義したのが P. ハロルドらのグループで、その特徴 は、(1)セクター全体が対象となる、(2)首尾一貫したセクター政策がある、(3)途上国側 
にオーナーシップがある、(4)全ての援助機関が参加する、(5)協力の手続きが共有され ている、(6)技術協力を最小限にする、である。Harold, Peter, and Associates, The Broad Sector Approach to Investment Lending: Sector Investment Programs, Washington, D.C., The World Bank Discussion Paper No. 302, 1995. また、プロジェクト型からセクター・プログ ラム型協力形態への変化を考察した、Buchert, Lene, “From Project to Programme to Sector Wide Support: Some Questions and Concerns," Prospect, Vol.XXX, No.4 (December), 2000, pp.405-408, 等がある。

(21) PRSP における教育分野の位置づけを検討したものとして、Caillods, Francoise, and Hallak, Jacques, Education and PRSPs: A Review of Experience, Paris: IIEP, UNESCO, 2004 . がある。

(22) Ratcliff, Mike and Macrae, Murray, Sector Wide Approaches to Education Development, London: DFID, 1999; 及び Sida, Sida's Policy for Sector Programme Support, Stockholm: Sida, 2000, 等を参照。

(23) 教育部門は保健部門と並び先駆的に SWAp が導入されている。つまり、教育部門は、 公的部門が支配的であり援助機関は直接に途上国政府との交渉が可能であること、政 府支出として予算規模の予見が可能であること、教育サービスの提供が地方政府の主 要な責任分野であること、多くの援助機関が優先分野として教育部門の支援を行って おり SWApに対する支持基盤があること、等がSWApに拈ける教育部門の優位性と なっている。

(24) 2001 年から 2005年までの PAP 対象として、11分野の教育サブ・セクターが選ばれて いる。Sub-Working Group No.3, “Education: Sector Wide Approach," Practices and Lessons Learned in the Management of Development Cooperation: Case Studies in Cambodia, Phnom Penh: Government-Donor Partnership Working Group, 2004, pp.39-58.

(25) ADB, RRP, Cambodia, Education Sector Development Program, Manila, 2001; 及び ADB, RRP, Cambodia, Second Education Sector Development Program, Manila, 2004.

(26) World Bank, PAD, Viet Nam, Primary Education for Disadvantaged Children, Washington, D.C., 2002; 及び ADB, RRP, Viet Nam, Second Lower Secondary Education Development Project, Manila, 2004. 同様の概念として、「最低サービス水準 (Minimum Service Standards)」 があり、インドネシアでの導入が計画されている。

(27) King, Kenneth, "The External Agenda of Educational Reform: A Challenge to Educational Self-Reliance and Dependency in Sub-Saharan Africa," Journal of International Cooperation in Education, Vol.7, No.1 (April 2004), pp.85-96.

(28) Samoff, Joel, "Education Sector Analysis in Africa: Limited National Control and Even Less National Ownership," International Journal of Educational Development, Vol.19, No.4-5 (July-September 1999), pp.249-272.

(29) 北村、前掲論文、2005年。 
(30) ADB, A Wealth of Opportunity: Development Challenges in the Mekong Region, Manila: $\mathrm{ADB}, 2000$; 及び拙稿「国際機関の役割と動向(二)—アジア開発銀行」内海編、前掲書、 115-129頁。同様の準地域協力の枠組みとしてブルネイ、インドネシア、マレーシア、 フィリピンにまたがる「東アセアン成長地域 (East ASEAN Growth Area)」プログラムが あるが、ミンダナオ島周辺の政情・治安状況によって、あまり進渉していない。

(31) 西澤信善「メコン川流域総合開発」北原淳・西澤信善編著『アジア経済論』ミネルヴア 書房、2004年、239-266頁。

(32) ADB, GMS Fifth Meeting of the Working Group on Human Resource Development, Yangon, Myanmar, July 2004.

(33) 横関、前揭論文。

(34) ADB, Technical Assistance Report, GMS Phnom Penh Plan for Development Management, Manila: ADB, 2002.

(35) 国際開発センター・コーエイ総合研究所『教育開発調査の経験と今後の教育開発プロ ジェクト』国際協力機構、2004年。

(36) すでに、1994年には第三国（特にインドシナ諸国）に対してタイが行う技術協力への 支援を促進していく「日・タイーパートナーシッププログラム」が導入されている。

(37) 例えば、北村友人「比較教育学と開発研究の関わりーコミットメント・アプローチに もとづく教育開発研究のあり方」比較教育学会創設 40 周年記念特別シンポジウム、名古 屋大学、2006年 6 月26日。

(38) McGinn, Noel F., "An Argument for Dialogue in Definition of National Policies for Education," Journal of International Cooperation in Education, Vol.7, No.1 (April 2000), pp. 15-25; 及び Hirosato, op.cit. アジア諸国が自らの教育改革能力の構築を目指す「アジア地 域教育計画・運営研究所 (仮称)」設立へ向けての実現可能性を調査すること、そのよう な機関設立の為の具体的な道程が提示されている。 